\title{
Correlation of Red Cell Distribution Width Value with Force Expiration Volume One Second in Patients with Stable Chronic Obstructive Lung Disease
}

\author{
Martunis Martunis ${ }^{1}$, Amira Permatasari Tarigan $^{1 \star}$, Muntasir Muntasir ${ }^{1}$, Putri Chairani Eyanoer $^{2}$ \\ ${ }^{1}$ Department of Pulmonology and Respiratory Medicine, Faculty of Medicine, Universitas Sumatera Utara, Medan, Indonesia; \\ ${ }^{2}$ Department of Community Medicine, Faculty of Medicine, Universitas Sumatera Utara, Medan, Indonesia
}

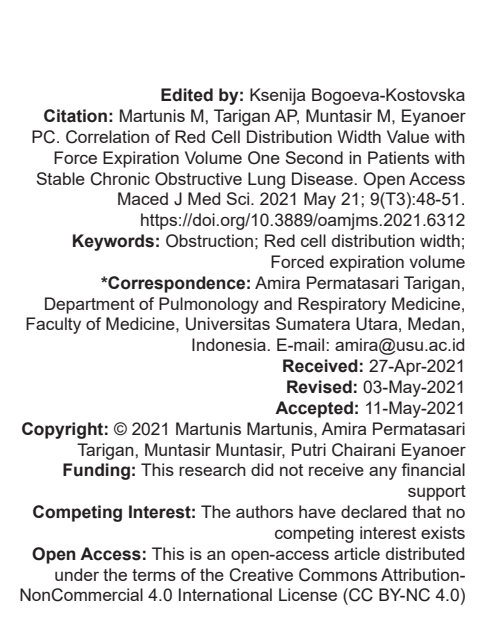

\section{Introduction}

Chronic obstructive pulmonary disease (COPD) is a common preventable and treatable disease characterized by persistent airway symptoms and airflow obstruction due to airway and/or alveolar abnormalities, generally due to significant exposure to harmful particles or gases.

A report from the Global Initiative for Chronic Obstructive Lung Disease states that in 2010 as many as 384 million people or around $11.7 \%$ of the world's population were COPD sufferers with a death rate of up to 3 million people each year. The World Health Organization itself states that by 2030, COPD will be the third leading cause of death worldwide [1]. The Indonesian Lung Doctors Association (PDPI) stated that in 2015, at least 4.5-5.5\% of Indonesia's population was suffering from COPD, and this figure could increase to $7.2 \%$ in rural areas [2].

Chronic inflammation that occurs in COPD does not only cause disturbances in the respiratory system but also has a significant systemic impact as a sign that there is a comorbid condition in the sufferer.

Red cell distribution width (RDW) is a simple and non-invasive parameter that can be used as a biomarker in evaluating the severity of COPD an d mortality rates in COPD patients in acute attacks [3]. RDW is a mathematical calculation that describes the number of anisocytosis (variation in cell size) and at a certain level describes poikilocytosis (variations in cell shape) of red blood cells on peripheral blood tests. RDW is a reflection of the coefficient of variation of the volume distribution of red blood cells. Normal values range from $11.5 \%$ to $14.5 \%$. The higher the RDW value, the greater the variation in cell size [4].

Several recent studies have reported a significantly increased RDW value in exacerbated COPD patients compared with stable COPD [5]. However, until now, there has been no study that has tested whether there is a relationship between the RDW value and the degree of airway obstruction measured using the first second forced expiratory volume (FEV1) parameter. This is the background for conducting a study to determine the relationship between RDW values and FEV1 values in stable COPD patients. 


\section{Methods}

This study is an analytical study with a crosssectional design conducted on patients at the PPOK Poli RSUP H Adam Malik, Medan, and the University of North Sumatra Hospital.

The research subjects were selected using consecutive sampling technique, where the inclusion criteria were patients aged $40-70$ years and willing to be research subjects by signing the consent form after explanation.

All study subjects underwent blood tests to determine the RDW value. The RDW value comes from the measurement of the erythrocyte histogram which is expressed in the form of RDW-SD (fL unit) or RDW-CV (\%). In addition, all study subjects underwent a spirometry examination to determine the value of the FEV1. All study subjects were also subjected to descriptions of clinical and demographic characteristics based on gender, age, smoking history, body mass index, degree of obstruction, Brinkman index, and mMRC score.

The correlation analysis between the RDW value and the FEV1 value was carried out using the Spearman correlation test, where $p<0.05$ was statistically significant.

\section{Results}

A total of 30 people with stable COPD who met the study criteria were included in this study. The characteristics of the research subjects are shown in Table 1.

Table 1: Characteristic of subjects

\begin{tabular}{|c|c|c|}
\hline Characteristic & $\mathrm{n}$ & $\%$ \\
\hline \multicolumn{3}{|l|}{ Gender } \\
\hline Male & 28 & 93.3 \\
\hline Female & 2 & 6.7 \\
\hline \multicolumn{3}{|l|}{ Age (years old) } \\
\hline $40-49$ & 4 & 13.3 \\
\hline $50-59$ & 14 & 46.7 \\
\hline $60-69$ & 12 & 40.0 \\
\hline \multicolumn{3}{|l|}{ Smoking history } \\
\hline Smoker & 26 & 86.7 \\
\hline Non-smoker & 4 & 13.3 \\
\hline \multicolumn{3}{|l|}{ BMI } \\
\hline Underweight & 8 & 26.7 \\
\hline Normoweight & 15 & 50.0 \\
\hline Overweight & 7 & 23.3 \\
\hline \multicolumn{3}{|c|}{$\% F E V 1$ predicted } \\
\hline $0-29.9$ & 15 & 50 \\
\hline $30-49.9$ & 10 & 33.3 \\
\hline $50-79.9$ & 5 & 16.7 \\
\hline $80-100 \%$ & 0 & 0 \\
\hline \multicolumn{3}{|l|}{ Score mMRC } \\
\hline mMRC 1 & 0 & 0 \\
\hline mMRC 2 & 13 & 43.3 \\
\hline mMRC 3 & 13 & 43.3 \\
\hline mMRC 4 & 4 & 13.3 \\
\hline \multicolumn{3}{|l|}{ Indeks Brinkman } \\
\hline Mild & 1 & 3.3 \\
\hline Moderate & 10 & 33.3 \\
\hline Heavy & 15 & 50 \\
\hline Non-smoker & 4 & 13.3 \\
\hline Total & 30 & 100.0 \\
\hline
\end{tabular}

Open Access Maced J Med Sci. 2021 May 21; 9(T3):48-51.
Table 2 shows the distribution of RDW values in study subjects based on sex, age, smoking history, and body mass index.

Table 2: RDW value of subjects

\begin{tabular}{|c|c|c|}
\hline Characteristic & Median & Min-Max \\
\hline \multicolumn{3}{|l|}{ Gender } \\
\hline Male & 12.7 & $11.2-18.1$ \\
\hline Female & 13.1 & $13.1-13.2$ \\
\hline \multicolumn{3}{|l|}{ Age (years old) } \\
\hline $40-49$ & 12.9 & $11.8-13.7$ \\
\hline $50-59$ & 12.9 & $11.4-16.5$ \\
\hline $60-69$ & 12.8 & $11.2-18.1$ \\
\hline \multicolumn{3}{|l|}{ Smoking history } \\
\hline Smoker & 12.8 & $11.2-18.1$ \\
\hline Non-smoker & 12.4 & $11.5-13.2$ \\
\hline \multicolumn{3}{|l|}{ BMI } \\
\hline Underweight & 15.2 & $12.2-18.1$ \\
\hline Normoweight & 12.1 & $11.2-16.5$ \\
\hline Overweight & 13.2 & $12.0-15.5$ \\
\hline \multicolumn{3}{|c|}{ \%FEV1 predicted } \\
\hline $0-29.9$ & 13.1 & $11.2-18.1$ \\
\hline $30-49.9$ & 12.9 & $11.6-16.5$ \\
\hline $50-79.9$ & 11.8 & $11.5-13.7$ \\
\hline \multicolumn{3}{|l|}{ Indeks Brinkman } \\
\hline Moderate & 13.1 & $11.2-16.5$ \\
\hline Heavy & 12.8 & $11.4-18.1$ \\
\hline Non-smoker & 12.4 & $11.5-13.2$ \\
\hline \multicolumn{3}{|l|}{ Score mMRC } \\
\hline mMRC 2 & 12.8 & $11.2-15.5$ \\
\hline mMRC 3 & 13 & $11.4-18.1$ \\
\hline mMRC 4 & 12.1 & $12.0-13.1$ \\
\hline
\end{tabular}

There was no difference in the RDW value between male and female subjects $(p=0.56)$. Statistical analysis also showed that there was no difference in RDW values between age groups $(p=0.96)$. Likewise, the RDW value based on smoking history, it was found that there was no significant difference in the RDW value for both smokers and non-smokers $(p=0.34)$.

Statistical analysis showed that there was a significant difference in RDW values based on the body mass index group $(p<0.05)$. COPD patients who are underweight have the highest RDW value which is 15.2 when compared to the RDW value in the normoweight and overweight groups.

The main objective of this study was to determine the correlation between the RDW value and the FEV1 value in patients with stable COPD as shown in Table 3:

Table 3: Correlation of RDW and FEV1

\begin{tabular}{llll}
\hline & Median (Min-Max) & $\mathrm{r}$ & $\mathrm{p}$-value \\
\hline RDW value & $12.8(11.2-18.1)$ & -0.21 & 0.25 \\
\%FEV1 predicted & $30.9(14.2-59)$ & & \\
\hline Spearman correlation test, \%FEV1: First second forced expiratory volume, RDW: Red cell distribution width
\end{tabular}

The results of statistical analysis showed that there was a weak negative correlation between the RDW value and the FEV1 value in stable COPD patients who were the research subjects, and the correlation was not statistically significant $(p>0.05)$

\section{Discussion}

RDW is a reflection of the coefficient of variation of the volume distribution of red blood cells. RDW is 
a numerical measure of the variability in the size of circulating erythrocytes and is a routine examination as a component of a complete blood count diagnosed versus anemia. The inflammatory response that arises in COPD patients will lead to the production of excess pro-inflammatory cytokines such as tumor necrosis factor a, IL-6, and interferon- $\gamma$ so that red blood cells shorten their life span.

The inflammatory response that arises in COPD patients will lead to the production of excess proinflammatory cytokines such as tumor necrosis factor a, IL-6, and interferon- $\gamma$ so that red blood cells shorten their lifespan, while compensation for production from bone marrow is insufficient due to the suppression of erythropoietin hormone production.

In COPD patients, red blood cell counts and hemoglobin levels can also be found because the body compensates for the increased secretion of the hormone erythropoietin which stimulates the production of red blood cells.

According to several previous studies, there is an association between high RDW levels and increased mortality of several diseases including COPD. RDW also increases in value as the severity of COPD disease increases. When compared with COPD patients who had not received therapy, the RDW values of patients in this study were normal but there was no significant difference between the LABACS and nonLABACS groups. This may be due to the non-LABACS group who are already using short acting beta-2 agonist therapy and it is sufficient to increase the RDW value to the normal range [6], [7], [8].

A recent population-based study reported a negative and independent association of RDW with lung function after eliminating the effects of potential confounders. The study could not determine any interaction between RDW and smoking and questioned the direct effects of RDW on pulmonary functions. However, in another study, smokers RDW levels were found to be higher than the ones associated with nonsmokers [9], [10].

The results of our study also demonstrated that pulmonary function test parameters were negatively associated with RDW. This finding was concordant with the high RDW levels we observed in severe COPD stages, especially in the very severe group.

Recent studies report that RDW increases with increasing degree or severity of COPD. This strengthens the hypothesis or opinion that RDW can be used as a biomarker in evaluating disease severity in patients with COPD. In COPD patients, red blood cell counts and hemoglobin levels can also be found because the body compensates for the increased secretion of the hormone erythropoietin which stimulates the production of red blood cells. In population D COPD patients who have experienced prolonged hypoxemia, the body will compensate by increasing erythrocyte production through stimulation of the hormone erythropoietin [6].

The etiopathogenesis of changes in the RDW\% value in individuals with pulmonary disorders remains to be identified. Chronic inflammation which can lead to the release of inflammatory cytokines exacerbated by mild nutritional deficiencies and smoking would be a potential mechanism that could lead to an increase in RDW in such cases [7].

The independent association between RDW and survival has been described for a broad spectrum of cardiovascular and pulmonary disease such as pulmonary hypertension, acute pulmonary embolism, idiopathic pulmonary fibrosis, and even for COPD.

The underlying mechanisms for the association between the RDW and mortality are currently unknown. Elevated RDW values may also be associated with low-grade inflammation that is present in chronic respiratory diseases. Inflammation induces changes in erythropoiesis, erythrocyte half-life, and erythrocyte membrane deformability [8].

These findings suggest that the RDW\% value increases with decreasing lung function, indicating the possibility of using RDW\% as a biomarker not only in identifying COPD but also as a marker, to assess the severity of obstructive pulmonary disease.

\section{Conclusion}

There is no significant correlation between the RDW value and the FEV1 value in patients with stable COPD. There is no relationship between age, sex, and smoking history with the RDW value in patients with stable COPD.

\section{References}

1. World Health Organization. WHO Burden of COPD. Geneva World Health Organization; 2017. Available from: http://www.who. int/respiratory/copd/burden/en. [Last accessed on 2017 Jan 28].

2. Amin M, editor. PPOK: Diagnosis dan Penatalaksanaan. Jakarta: UI Press; 2016.

3. Rahimirad S, Ghafari M, Ansarin K, Rashidi F, Rahimi-Rad MH Elevated red blood cell distribution width predicts mortality in acute exacerbation of COPD. Pneumologia. 2016;65(2):85-9. PMid:29542313

4. Lippi G, Targher G, Montagnana M, Salvagno GL, Zoppini G, Guidi GC. Relation between red blood cell distribution width and inflammatory biomarkers in a large cohort of unselected out patients. Arch Pathol Lab Med.2009;133(4):628-32. https://doi. org/10.5858/133.4.628

PMid:19391664 
5. Seyhan EC, Özgül MA, Tutar N, Ömür I, Uysal A, Altin S. Red blood cell distribution and survival in patients with chronic obstructive pulmonary disease. COPD. 2013;10(4):416-24. https://doi.org/10.3109/15412555.2012.758697

PMid:23537076

6. Astuti T, Karima T, Iskandar A. The difference in Haemoglobin and Erythrocyte Parameters in Chronic Obstructive Pulmonary Disease with and without Inhalation Therapy with Combinations of Long Acting Beta 2 Agonist and Corticosteroid. Majalah Kesehatan Brawijaya. 2019;6(3): 15-9. https://doi.org/10.21776/ ub.majalahkesehatan.2019.006.03.3

7. Subhashree AR, Shanthi B, Parameaswari PJ. The red cell distribution width as a sensitive biomarker for assessing the pulmonary function in automobile welders a cross sectional study. J Clin Diagn Res. 2013;7(1):89-92. https://doi. org/10.7860/jcdr/2012/5051.2678
PMid:23449620

8. Tertemiz KC, Alpaydin AO, Sevinc C, Ellidokuz H, Acara AC Cimrin A. Could "red cell distribution width" predict COPD severity? Rev Port Pneumol. 2016;22(4):196-201. https://doi. org/10.1016/j.rppnen.2015.11.006

PMid:26809230

9. Perlstein TS, Weuve J, Pfeffer MA, Beckman JA. Red blood cell distribution width and mortality risk in a community-based prospective cohort. Arch Intern Med. 2009;169(6):588-94. https://doi.org/10.1001/archinternmed.2009.55

PMid: 19307522

10. Patel KV, Semba RD, Ferrucci L, Newman AB, Fried LP, Wallace RB, et al. Red cell distribution width and mortality in older adults: A meta-analysis. J Gerontol A Biol Sci Med Sci. 2010;65(3):258-65.

PMid: 19880817 